\title{
Evaluation of the bending strength of rigid internal fixation with absorbable and metallic screws in mandibular ramus sagittal split osteotomy - in vitro study
}

\section{Avaliação da resistência à flexão da fixação interna rígida, com parafusos absorvíveis e metálicos, na osteotomia sagital do ramo mandibular - estudo in vitro}

Petrus Pereira Gomes*

Rubens Guimarães Filho**

Renato Mazzonetto***

\begin{abstract}
The aim of this study was to evaluate, in vitro, the bending strength of internal fixation with absorbable and metallic screws in mandibular ramus sagittal split osteotomy in sheep hemimandibles. The screws were inserted as lag screws, with an inverted " $L$ " configuration, and the set was submitted to bending strength tests. The load and displacement of the peak and final load averages were, respectively, $18.45 \mathrm{kgf}, 8.19 \mathrm{~mm}$ and $14.38 \mathrm{kgf}$ for Group I, and $16.67 \mathrm{kgf}, 6.73 \mathrm{~mm}$ and $13.98 \mathrm{kgf}$ for Group II. The results were submitted to statistical analysis by Student's $t$ test and by the Pearson correlation analysis. The groups showed no statistically significant differences, indicating the feasibility of both for osteosynthesis in mandibular ramus sagittal split osteotomies.

DESCRIPTORS: Osteotomy; Fracture fixation, internal; Mandibular advancement; Lactic acid.
\end{abstract}

RESUMO: O objetivo deste estudo foi avaliar, in vitro, a resistência à flexão da fixação interna, através do uso de parafusos absorviveis e metálicos, na osteotomia sagital do ramo em hemimandíbulas de carneiros. Os parafusos foram inseridos como "lag screw", com configuração em "L" invertido e o conjunto submetido ao teste de resistência à flexão. As médias da carga e do deslocamento do pico e da carga final do Grupo I foram de 18,45 kgf, 8,19 mm e 14,38 kgf, e do Grupo II de 16,67 kgf, 6,73 mm e 13,98 kgf, respectivamente. Os resultados foram submetidos à análise estatística pelo teste $t$ de Student e pela análise de correlação de Pearson. Os grupos exibiram diferenças estatisticamente não significativas, indicando a viabilidade de ambos para a osteossintese em osteotomias sagitais do ramo mandibular. DESCRITORES: Osteotomia; Fixação interna de fraturas; Avanço mandibular; Ácido láctico.

\section{INTRODUCTION}

The introduction of mandibular ramus sagittal split osteotomy, by Trauner, Obwegeser ${ }^{26}$ (1957), represented a great advance in the correction of dentofacial deformities. Successive modifications of the technique were suggested, mainly for increasing the stability of the fixed segments ${ }^{11,28}$. Spiess $1^{23}$ (1974) was the first to employ screws for fixing mandibular ramus sagittal osteotomies, using the lag screw technique with three $2.7 \mathrm{~mm}$ screws positioned in an inverted " $\mathrm{L}$ ".

A wide variety of osteosynthesis materials and techniques have been employed by intra/extraoral accesses, including plates with mono- and bicortical screws, whether or not associated with maxil- lomandibular fixation (MMF) or skeletal fixation and positional or lag screws ${ }^{9}$. Osteosynthesis materials should have some ideal characteristics like ease of use, the ability to fix adequately to bone segments, biocompatibility, and should be able to gradually transfer physiological loads to the bone being repaired. They should also be absorbed after they have completed their function ${ }^{16}$. Metallic materials like titanium have excellent properties for use in osteosynthesis. There are, however, some disadvantages described in the literature, like the release of metallic ions, continual mechanical stimulus, osteolysis under the implants ${ }^{21}$, interference in radiotherapy, production of artifacts in computerized tomography and magnetic resonance, occurrence of corrosion and allergic reac-

\footnotetext{
*Doctorate Student; **PhD; ***Associate Professor - Oral and Maxillofacial Surgery, School of Dentistry of Piracicaba, State University of Campinas.
} 
Gomes PP, Guimarães Filho R, Mazzonetto R. Evaluation of the bending strength os rigid internal fixation with absorbable and metallic screws in the mandibular ramus sagittal split osteotomy - in vitro study. Pesqui Odontol Bras 2003;17(3):267-72.

tions, and the palpability and hypersensitivity to cold $^{1}$.

Kulkarni et al. ${ }^{19}$ (1966) were the first authors to experimentally evaluate the employment of absorbable materials. Cutright et al. ${ }^{6}(1971)$ reported the use of absorbable fixation for stabilizing mandibular fractures in monkeys. Important advances have occurred with the employment of this technique, especially with regard to the chemical composition of materials, clinical and biomechanical properties, and the forms of presentation. Polylactic acid (PLA), which is absorbed by hydrolysis, is the most commonly employed material in oral and maxillofacial surgery ${ }^{16}$. Törmälä et al. ${ }^{25}$ (1988) introduced the self-reinforcement techniques in the production of PLA, thus significantly increasing its mechanical properties. The absorbable materials are outstanding due to the ability of not requiring removal after the bone repair period, thus eliminating a second surgical procedure. Furthermore, they do not interfere in the treatment with radiotherapy and do not generate artifacts in computerized tomography and magnetic resonance examinations. Studies indicate that the absorbable osteosynthesis systems gradually lose mechanical strength, a loss that generally becomes significant after about six months, which is sufficient for bone consolidation. The total absorption time of these materials is not yet known, varying according to chemical composition, place of implantation and the amount of material used ${ }^{5}$.

The aim of this experimental study is to evaluate, in vitro, the bending strength of an internal fixa- tion carried out with the use of absorbable and metallic screws of equal diameter, inserted as lag screws.

\section{MATERIALS AND METHODS}

The bending strength tests were carried out on 20 right hemimandibles of adult sheep supplied by a slaughterhouse. All the soft tissues enveloping them were removed. The mandibular ramus sagittal split osteotomy in the hemimandibles was carried out by using a fissure cone bur, mounted on a handpiece coupled to an electrical motor, following the precepts of Trauner, Obwegeser ${ }^{26}$ (1957) with the modifications of Dal Pont ${ }^{7}$ (1961) and Hunsuck $^{15}$ (1968). After the osteotomy, the distal segment was advanced by $5 \mathrm{~mm}$. To fix the hemimandible segments, screws with $2.0 \mathrm{~mm}$ external diameters and $12 \mathrm{~mm}$ long were inserted as lag screws. The specimens were divided into two groups, Group I being constituted of 10 hemimandibles, each fixed with three absorbable screws of self-reinforced polylactic acid copolimer (SR-PLA, Bionx Implants, Tampere, Finland) 70L:30DL. Group II comprised 10 hemimandibles, each fixed with three commercially available pure titanium screws (Osteomed, Addison, Texas, United States of America).

The screws were inserted $90^{\circ}$ with the lateral bone surface throughout threading. Insertion was considered to be complete when the screw head touched the buccal cortical, and the extremity of the screw passed the medial cortical. After being fixed the hemimandibles had the posterior edge of

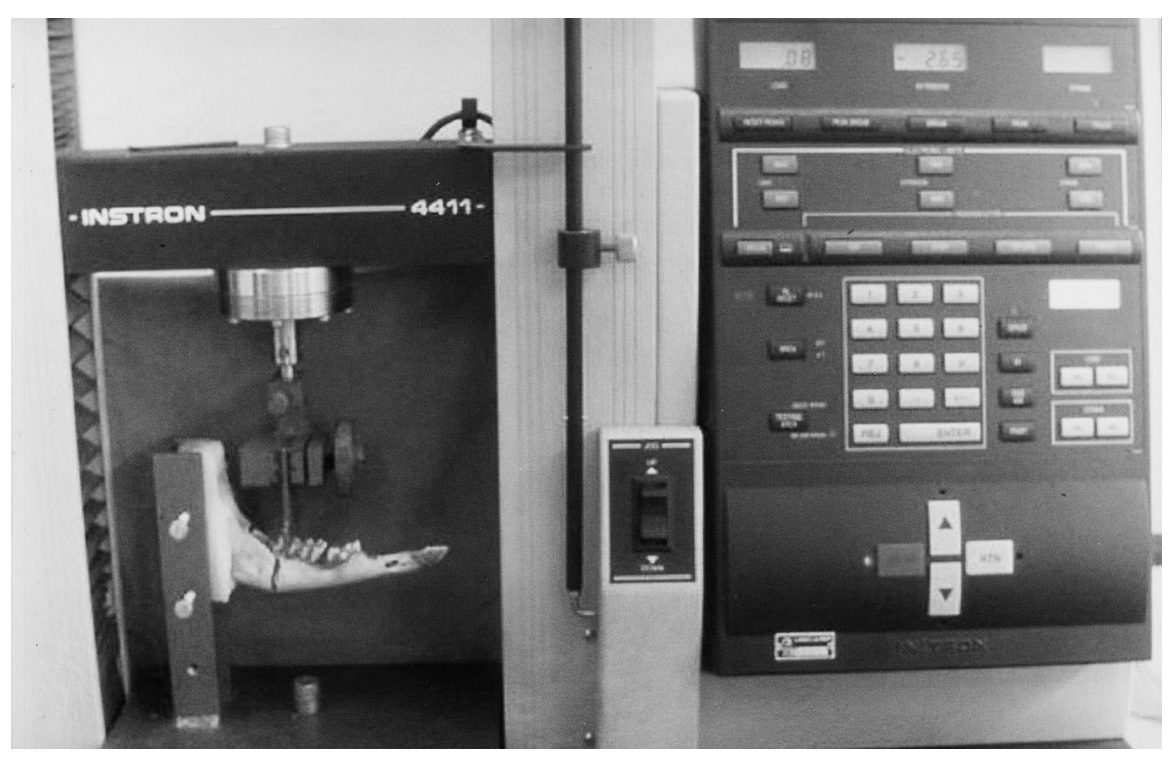

FIGURE 1 - Instron ${ }^{\circledR}$ machine during the experimental study. 
Gomes PP, Guimarães Filho R, Mazzonetto R. Evaluation of the bending strength os rigid internal fixation with absorbable and metallic screws in the mandibular ramus sagittal split osteotomy - in vitro study. Pesqui Odontol Bras 2003;17(3):267-72.

the ramus and condyle embedded in an acrylic resin block.

The hemimandibles, adapted to a fixing device, were taken for bending tests in an Instron ${ }^{\circledR}$ universal test machine (Instron Co., Canton, Massachusetts, USA) - model 4411 (Figure 1). The speed was set at $1 \mathrm{~mm} / \mathrm{min}$, with maximum displacement of $10 \mathrm{~mm}$, for the application of a progressive load to the system. The load was always applied vertically in the area between the last two molar teeth of each hemimandible. The progression of loading and displacement was followed on the machine monitor, and the load data in kilogram-force (kgf), and extent in millimeters $(\mathrm{mm})$ of any peak during the experiment were noted. When the final displacement of $10 \mathrm{~mm}$ was reached, a reading was made of the value corresponding to the final load, in kilogram-force (kgf).

Statistical analysis of the values obtained was carried out using Student's $t$ test and by the Pearson correlation analysis at a significance level of $5 \%$.

\section{RESULTS}

Student's $t$ test was applied to Groups I and II with regard to the mean values of the peak displacement $(p=0.23)$, of the peak load $(p=0.55)$ and of the final load $(\mathrm{p}=0.88)$ (Table 1$)$. For all the data,

TABLE 1 - Mean value of peak displacement, peak load and final load.

\begin{tabular}{c|c|c|c}
\hline \hline Groups & $\begin{array}{l}\text { Peak } \\
\text { displacement }\end{array}$ & Peak load & Final load \\
\hline Group I & $8.19 \mathrm{~mm}$ & $18.45 \mathrm{kgf}$ & $14.38 \mathrm{kgf}$ \\
\hline Group II & $6.73 \mathrm{~mm}$ & $16.67 \mathrm{kgf}$ & $13.98 \mathrm{kgf}$ \\
\hline \hline
\end{tabular}

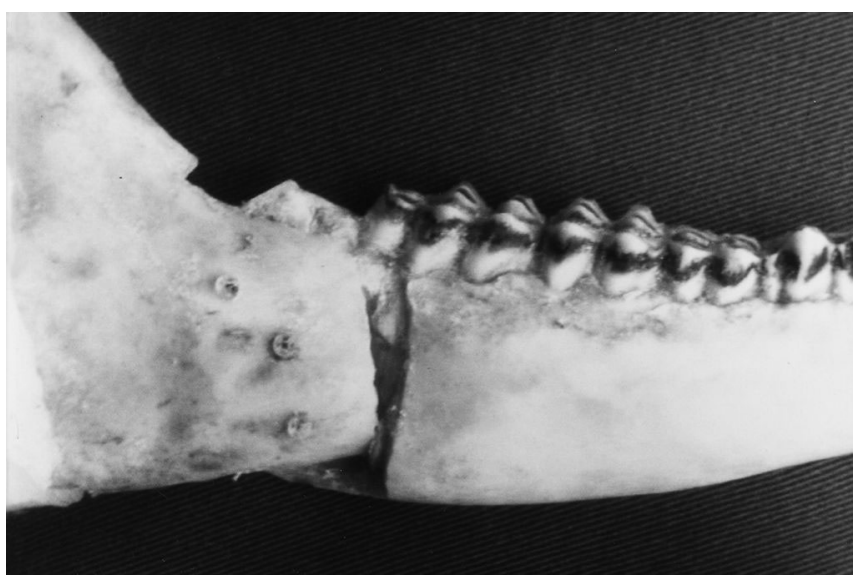

FIGURE 2 - Bend of distal segment, by absorbable screw deformation. the difference between both groups was not statistically significant.

The Pearson correlation analysis was applied to the peak and final loads, independently, for each of the groups. Group I showed a positive correlation between the peak and final loads ( $p=0.007)$, whereas in Group II there was no correlation between the respective peak and final loads $(\mathrm{p}=0.22)$.

The analysis of Group I showed that the distal segment of the hemimandibles underwent bending throughout the extent of the displacement $(10 \mathrm{~mm})$, by means of the area of contact between the osteotomy segments, without evidence of bone fracture in the region where the screws were inserted (Figure 2). In Group II, however, the distal segment underwent less bending, which may explain the horizontal bone fractures on the areas where the metallic screws were inserted (Figure 3).

\section{DISCUSSION}

The mandibular ramus sagittal split osteotomy is the most widely employed procedure for correcting dentoskeletal deformities in the mandible ${ }^{20}$. The wide dissemination of this technique is possibly related to its versatility and to the favorable results that have been obtained ${ }^{26}$.

In this study, all the distal segments of the hemimandibles were advanced by $5 \mathrm{~mm}$, thus keeping a reference standard in conformity with other studies that evaluated the stability and fixation methods of mandibular ramus sagittal osteotomy $^{10,27}$.

The sheep mandible has been used for experimental studies of osteotomies and rigid internal fixation in the ramus area, mainly due to the similarities in format, size and structure to the human

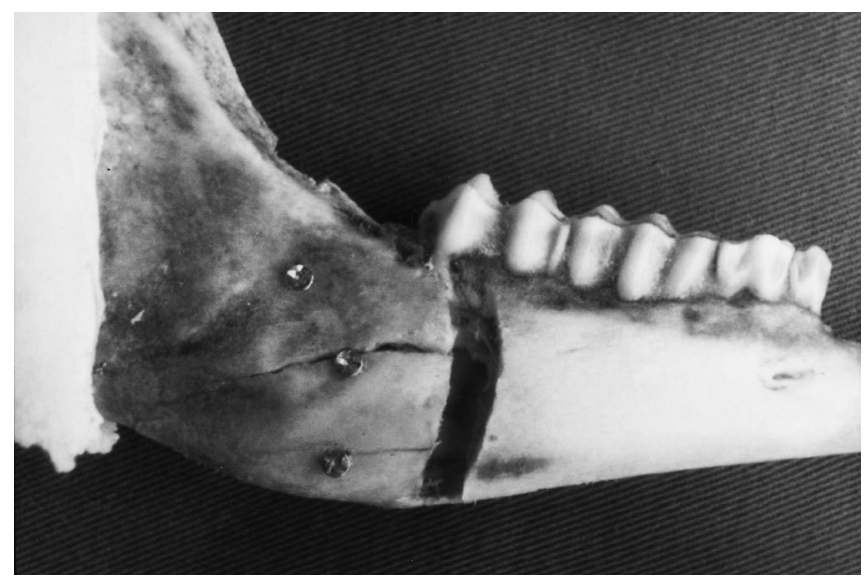

FIGURE 3 - Lateral cortical fractures on the proximal segment, common in the metallic screw group. 
Gomes PP, Guimarães Filho R, Mazzonetto R. Evaluation of the bending strength os rigid internal fixation with absorbable and metallic screws in the mandibular ramus sagittal split osteotomy - in vitro study. Pesqui Odontol Bras 2003;17(3):267-72.

mandible ${ }^{27}$. It is important to emphasize that the data obtained from biomechanical studies using analogous bones cannot be directly transferred to clinical use in humans, serving only as indicative parameters of the behavior of a certain technique and/or material.

Since Spiess ${ }^{23}$ described, in 1974 , the osteosynthesis technique with screws, investigations have been carried out with regard to whether or not should the bone corticals be compressed ${ }^{22}$, as the use of screws, like the lag screw, would permit a greater surface compression area, thus favoring bone tissue stability and primary bone repair without the development of bone callus. There are no statistically significant differences between the stability provided by positional screws and by the lag screw technique when used for osteosynthesis of segments in sagittal split osteotomy ${ }^{13}$.

Different numbers and configurations of screws employed for rigid internal fixation have been evaluated. It is known, however, that the use of one screw is unacceptable and that stabilization with two screws is still a method with few documented reports. The use of three screws seems to be the ideal, as the addition of more screws shows no mechanical advantage ${ }^{14}$. In this study, the option was to use the inverted "L" configuration for fixation of the hemimandibles, as this is the most acceptable pattern and one that provides the greatest resistance to displacement of the fixed segments after mandibular ramus sagittal split osteotomy ${ }^{14}$.

The biomechanical test employed a two-dimensional model with a free end lever, due to the facility of obtaining data, lower cost and ease of use. It was, however, not able to simulate the complex behavior of the human mandible at work. The load peaks generated in some specimens during the bending test probably occurred due to the sudden reductions in biomechanical resistance of the system at some moment during load application, and this could have been the point of failure in these hemimandibles. In the other specimens, there was a progression of loading and displacement without the occurrence of peaks, so the final displacement $(10 \mathrm{~mm})$ was considered as the point of failure. One should consider, however, that a displacement of $10 \mathrm{~mm}$ is far in excess of the clinical and radiographic limit of what would be considered a failure of the fixation system. According to Ardary et al. ${ }^{2}$ (1989), this limit would be $1 \mathrm{~mm}$.

The results indicated that there were no statistically significant differences between the groups, as both attained the final displacement proposed for the study, with similar final load averages, in spite of the individual variation of the values in the samples. This suggests that possibly the absorbable osteosynthesis system in this study showed bending strengths comparable to those of the metallic system.

However, the elasticity module of the SR-PLA (70L:30DL) screws, $6 \mathrm{GPa}$, is similar to that of the cortical bone, 5 to $30 \mathrm{GPa}$, while the metallic material reaches around $200 \mathrm{GPa}^{17}$. Perhaps this justifies the finding in some hemimandibles after the bending test (Figures 2 and 3). Tate et al. ${ }^{24}$ (1994) found masticatory forces in the molar area of up to $13.8 \mathrm{kgf}$, in the first six weeks, compared to forces of $26 \mathrm{kgf}$ after the sixth post-operative week of surgical treatment of mandibular angle fractures. The importance of these data is that they are maximum forces obtained during occlusion, and that the amount of force used during functional activities is probably much less. This explains why forms of fixation with less rigid materials may be successfully used. Clinically, the amount of resistance to load necessary for a fixation material to promote adequate bone repair in a functional mandible is unknown ${ }^{18}$.

Experimental studies in vitro and in vivo have employed absorbable plates and screws of greater thickness and diameter, respectively, for carrying out osteosynthesis in fractures and mandibular osteotomies, with the objective of compensating for the lower mechanical resistance of the absorbable materials in relation to metallic ones ${ }^{12}$. In the sagittal split osteotomy, few studies describe the use of screws of up to $2.0 \mathrm{~mm}$ for RIF (rigid internal fixation) ${ }^{8}$. The time for total absorption of SR-PLA (70L:30DL) screws in vivo is unknown. The direct information about the total absorption time of PLA in humans is based on a few studies with biopsies taken in reoperations ${ }^{3}$. Extrapolation of the hydrolysis studies in vitro suggests that the complete degradation of SR-PLA (70L:30DL) would take from two to three years. The tissue response to the absorbable materials does not seem to be a problem when materials with more amorphous characteristics are used, which would facilitate absorption.

The absorbable materials appeared as an alternative to attempt to overcome possible problems with the metallic osteosynthesis ${ }^{4,21}$, such as the release of metal ions, the continuous mechanical stimulus, interference in radiography, and the pro- 
Gomes PP, Guimarães Filho R, Mazzonetto R. Evaluation of the bending strength os rigid internal fixation with absorbable and metallic screws in the mandibular ramus sagittal split osteotomy - in vitro study. Pesqui Odontol Bras 2003;17(3):267-72.

duction of artifacts in tomographic and magnetic resonance examinations. Some factors, like the high cost and greater dimension of plates and screws, still prevent the total adoption of absorbable fixation. The question, therefore, is not whether or not to replace one fixation system with another, but to acknowledge the existence of two biologically and mechanically compatible osteosynthesis methods, which may be used according to the surgeon's and/or patient's preference.

\section{CONCLUSIONS}

Analyzing the data obtained under the experimental conditions of this study, it may be concluded that the existence of peaks appeared to be related to the abrupt reduction of the system's mechanical strength at some moment in the experiment. During the bending tests, the absorbable screws tended to bend in the same direction as the displacement of the distal segment, while the metallic screws resisted deformation, generating hori-

\section{REFERENCES}

1. Ahn DK, Sims CD, Randolph MA, O'Connor D, Butler PE, Amarante MT, et al. Craniofacial skeletal fixation using biodegradable plates and cyanoacrylate glue. Plast Reconstr Surg 1997;99:1508-17.

2. Ardary WC, Tracy DJ, Brownridge GW 2nd, Urata MM. Comparative evaluation of screw configuration on the stability of the sagittal split osteotomy. Oral Surg Oral Med Oral Pathol 1989;68:125-9.

3. Bergsma EJ, Rozema FR, Bos RR, deBruijn WC. Foreign body reactions to resorbable poly (L-lactide) bone plates and screws used for the fixation of unstable zygomatic fractures. J Oral Maxillofac Surg 1993;51:666-70.

4. Bos RRM, Rozema FR, Boering G, Nijenhuris AJ, Pennings AJ, Verwey AB. Bio-absorbable plates and screws for internal fixation of mandibular fractures. A study in six dogs. Int J Oral Maxillofac Surg 1989;18:365-9.

5. Böstman O, Pihlajamäki H. Clinical biocompatility of biodegradable orthopaedic implants for internal fixation: a review. Biomaterials 2000;21:2615-21.

6. Cutright DE, Hunsuck EE, Beasley JD. Fracture reduction using a biodegradable material, polylactic acid. J Oral Surg 1971;29:393-7.

7. Dal Pont G. Retromolar osteotomy for the correction of prognathism. J Oral Surg Anesth Hosp Dent Serv 1961; 19:42-7.

8. Edwards R, Kiely KD, Eppley BL. Resorbable fixation techniques for genioplasty. J Oral Maxillofac Surg 2000; 58:269-72.

9. Ellis E 3rd. Rigid fixation in orthognathic surgery. Selected Read Oral Maxillofac Surg 1992;2:1-17.

10. Ellis E 3rd, Reynolds S, Carlson DS. Stability of the mandible following advancement: a comparison of three postsur- zontal fracture lines over the lateral surface of the proximal segment.

Differences in final load values were not statistically significant between both groups, indicating that the mechanical strengths of absorbable and metallic screws under these experimental conditions were similar. The absorbable material may therefore be considered a feasible alternative for rigid internal fixation in mandibular ramus sagittal split osteotomies.

A larger number of studies still need to be developed to compare absorbable fixations of similar dimensions to those of metallic ones in fractures and mandibular osteotomies. The tests carried out with absorbable material in areas upon which greater loads fall, like the mandible, will supply consistent data and greater security for the dissemination of such systems. Furthermore, the biological behavior of these materials should also be the object of further investigations.

gical fixation techniques. Am J Orthod Dentofacial Orthop 1988;94:38-49.

11. Epker BN. Modifications in the sagittal osteotomy of the mandible. J Oral Surg 1977;35:157-9.

12. Eppley BL. Use of a resorbable fixation technique for maxillary fractures. J Craniofac Surg 1998;9:317-21.

13. Foley WL, Frost DE, Paulin WB, Tucker MR. Internal screw fixation: comparison of placement pattern and rigidity. $\mathrm{J}$ Oral Maxillofac Surg 1989;47:720-3.

14. Haug RH, Barber JE, Punjabi AP. An in vitro comparison of the effect of number and pattern of positional screws on load resistance. J Oral Maxillofac Surg 1999;57:300-8.

15. Hunsuck EE. A modified intraoral sagittal splitting technic for correction of mandibular prognathism. J Oral Surg 1968;26:250-3.

16. Kallela I. Rigid internal fixation of the mandible using biodegradable polylactide screws and metal screws: a clinical and experimental study [Academic Dissertation]. Helsinki: Medical Faculty of the University of Helsinki; 1999.

17. Kallela I, Tulamo RM, Hietanen J, Pohjonen T, Suuronen $\mathrm{R}$, Lindqvist C. Fixation of mandibular body osteotomies using biodegradable amorphous self-reinforced (70L:30DL) polylactide or metal lag screws: an experimental study in sheep. J Craniomaxillofac Surg 1999; 27:124-33.

18. Kim HC, Essaki S, Kameyama T. Comparison of screw placement patterns on the rigidity of the sagittal split ramus osteotomy: technical note. J Craniomaxillofac Surg 1995; 23:54-6.

19. Kulkarni RK, Pani KC, Neuman C, Leonard F. Polylactic acid for surgical implants. Arch Surg 1966;93:839-43.

20. Martis CS. Complications after mandibular sagittal split osteotomy. J Oral Maxillofac Surg 1984;42:101-7. 
Gomes PP, Guimarães Filho R, Mazzonetto R. Evaluation of the bending strength os rigid internal fixation with absorbable and metallic screws in the mandibular ramus sagittal split osteotomy - in vitro study. Pesqui Odontol Bras 2003;17(3):267-72.

21. Paavolainen P, Karaharju E, Slatis P, Ahonen J, Holmstrom T. Effect of rigid plate fixation on structure and mineral content of cortical bone. Clin Orthop 1978; 136:287-93.

22. Souyris F. Sagittal splitting and bicortical screw fixation of the ascending ramus. J Maxillofac Surg 1978;6:198-203.

23. Spiess1 B. Ostéosynthèses bei sagittaler osteotomie nach Obwegwser-Dal Pont. Fortschr Kiefer Gesichtschir 1974; 18:145-8

24. Tate GS, Ellis E 3rd, Throckmorton G. Bite forces in patients treated for mandibular angle fractures: implications for fixation recommendations. J Oral Maxillofac Surg 1994; 52:734-6.
25. Törmälä P, Rokkanen P, Laiho J, Tamminmäki M, Vainionpää S. U.S. Patent n. 4743267. Material for osteosynthesis devices; 1988.

26. Trauner R, Obwegeser $H$. The surgical correction of mandibular prognathism and retrognathia with consideration of genioplasty. Oral Surg Oral Med Oral Pathol 1957; 10:677-89.

27. Uckan S, Schwimmer A, Kummer F, Greenberg AM. Effect of the angle of the screw on the stability of the mandibular sagittal split ramus osteotomy: a study in sheep mandibles. Br J Oral Maxillofac Surg 2001;39:266-8

28. Wyatt WM. Sagittal ramus split osteotomy: literature review and suggested modification of technique. $\mathrm{Br} \mathrm{J}$ Oral Maxillofac Surg 1997;35:137-41.

Recebido para publicação em 12/09/02 Enviado para reformulação em 12/03/03 Aceito para publicação em 29/05/03 